\title{
ANIMAL MANURE FUNCTIONS AS SOIL AMENDMENT FOR URBAN GREEN SPACE IN THE LOESS PLATEAU
}

\author{
Zhang, J. W. ${ }^{1}-$ Huang, M. S. $.^{2 *}-$ Petropoulos, ${ }^{3}{ }^{3}$ Song, L. ${ }^{4}-$ He, S. Y. ${ }^{5,6}$ \\ ${ }^{1}$ State Key Laboratory of Soil and Sustainable Agriculture, Institute of Soil Science, Chinese \\ Academy of Sciences, Nanjing, PR China \\ ${ }^{2}$ Beijing Capital Co., LTD, Beijing, PR China \\ ${ }^{3}$ School of Engineering, Newcastle University, Newcastle upon Tyne, NE1 7RU, UK \\ ${ }^{4}$ Nanjing Dechuang Environmental Protection Technology Co. LTD, Nanjing, PR China \\ ${ }^{5}$ Institute of Agricultural Resources and Environment, Jiangsu Academy of Agricultural \\ Sciences, Nanjing, PR China \\ ${ }^{6}$ School of Environment and Safety Engineering, Jiangsu University, Zhenjiang, PR China \\ *Corresponding author \\ e-mail:hms@capitalwater.cn; phone:+86-025-8688-1367; fax: +86-025-8688-1000
}

(Received $17^{\text {th }}$ Sep 2019; accepted $8^{\text {th }}$ Jan 2020)

\begin{abstract}
Urban green space could efficiently tackle surface water management issues in modern cities, especially in the Loess Plateau where the urban environment is constrained by poor soil quality as well as limited and unevenly distributed precipitation. Numerous studies based on farmland have demonstrated that organic amendments could improve soil quality and the water holding capacity by increasing soil organic matter content and aggregate stability via functions of soil microorganisms. In this case, we show that organic amendments that successfully applied in agriculture could also be served to improve the soil quality underneath the urban green space in the Loess Plateau. On the whole, organic amendments performed better than inorganic ones. Specifically, animal manure imposed the greatest beneficial effects on soil water holding capacity, soil aggregation, as well as microbial diversity and activity, followed by plant residue and mushroom residue. In contrast, polyvinyl alcohol and volcanic pumice imposed no obvious, if not negative, effect on soil properties. In conclusion, animal manure could be a good soil amendment for urban green space, especially in the arid area of the Loess Plateau or other regions with similar soil properties.

Keywords: Sponge City, water storage and conservation, aggregate stability, soil organic matter, organic amendment
\end{abstract}

\section{Introduction}

"Sponge City" is a novel urban operational concept that aims to make city a more livable environment, with focus on tackling urban water management issues, such as purification of surface runoff, attenuation of peak as well as water conservation (Chan et al., 2018). As core component of this concept, urban green space could efficiently tackle those problems that coming with the rapid urbanization and industrialization, such as air pollution (Chen et al., 2019), heat-island effect (Cai et al., 2019), surface-water management (Chan et al., 2018). To achieve these purposes, it is necessary to transform the traditional urban conditions accordingly, especially the soil underneath the green space. Regarding the soil amelioration in urban green space, related studies mainly focused on the soils that were contaminated by heavy metals (Khan et al., 2017) and/or organic pollutants (Gong et al., 2016), while ignored those that were unpolluted but 
constrained by fragile structure and poor fertility. But soil natural quality (physical, chemical and biological properties) could also affect directly and/or indirectly the health of urban soil and the corresponding ecological functions, including the environmental livability and urban landscape (Vienneau et al., 2017).

As core component of soil physical quality, soil aggregates are groups of soil particles that bind to each other more closely than to adjacent particles (Follett et al., 2009). Often, the stability of soil aggregate can indicate the formation, stabilization and degradation of the soil structure (Verchot et al., 2011). In general, soils with an optimum level of aggregation will be more resistant to rapid water penetration and erosion (Karlen et al., 2008). Soil organic matter (SOM) is another indicator of soil quality because of its important roles including biological functions regarding the growth of beneficial soil microorganisms; chemical functions regarding the cycling and supplying essential plant nutrients; physical functions regarding the soil structure, runoff, as well as water and air transmission (Karlen et al., 2008; Zou et al., 2015; Tang et al., 2018; Zhang et al., 2018). Often, the stability and content of soil aggregates are positively correlated with soil fertility because the cohesion of aggregates is promoted mainly by organic polymer binding agents (Zhang et al., 2018). For example, Loess, an aeolian deposit, is primarily composed of silt-sized particles $(<2.0 \mathrm{~mm})$, and it is indeed constrained by both fragile soil structure and low soil organic matters (Guo et al., 2019). Such soil formation occurs widely around the world with the most extensive distribution in China (Sun, 2002; Hua et al., 2016). Influenced by continental monsoons and large variation in seasonal precipitation, the Loess soil often induces severe environmental disasters ( $\mathrm{Xu}$ and Wang, 2016), i.e. the easily slaked soil aggregates lead to soil collapse in rainstorm, while cause severe drought/dust in dry season (Tisdall and Oades, 1982).

Currently, soil amelioration mainly focuses on agricultural system (Karlen et al., 2008; Zhang et al., 2011). Numerous studies have reported successful application of, both organic and inorganic, soil amendments on improving soil structure and fertility (Miao et al., 2013; Chang et al., 2019; Su et al., 2019). Organic amendments, such as typical agricultural residues - animal manure and plant straw - are widely applied to improve soil fertility mainly by introducing amount of organic carbon as well as other nutrient/resources. Soil microbial community stimulated by these increased substrate could accelerate the formation of soil organic matters (SOM), with which to increase the binding of soil particles and soil aggregation (Peregrina et al., 2012; Feng et al., 2015; Wang et al., 2018). For example, in North China Plain, after 2 - 4 years of manure application, indigenous Bacillus asahii becomes the predominant population, which plays a key role of increasing crop yield and soil fertility (Feng et al., 2015). There are also many synthetic organic polymers that applied in soil amelioration practice for a long time (Stefanson, 1973; Wu et al., 2010). Take polyvinyl alcohol (PVA), a type of uncharged but hydrophilic synthetic organic polymer for example. With the attachment between polymer and clay surface by hydrogen binding, PVA could efficiently defend surface soil from rainfall shock in clay soil (Stefanson, 1973; Wiśniewska, 2010), and they have already applied to improve soil aggregation, hydraulic conductivity and decrease water evaporation with quite stable performance (Bouranis et al., 2008). For inorganic amendment, volcanic pumice (VOP) is a widely-used naturally-suited soil conditioner with numerous benefit for soil properties. With its porous structure on surface and more than 70 trace minerals inside, VOA could promote soil moisture retention and nutrient availibility, stimulate soil aggregation and enhance soil drainage, and it doesn't decompose, rot or blow away (Noland et al., 1992; Temiz and Cayci, 2018). However, 
due to limited investigation, it is not clear whether these soil amelioration practices in the agricultural system are still effective in urban green space.

In this study, we conducted an experiment to estimate the effect of several soil amendments (organic vs. inorganic) on the physical and biological properties of the soils underneath urban green space in Guyuan, a typical small city located in the central of the Loess Plateau. More than 50\% of Guyuan annual precipitation falls during summer, most of which are in heavy storms (Zhang et al., 2014), causing urban waterlogging and soil collapse, threatening the construction and maintenance of urban infrastructures (Liu et al., 2015). In contrast, the rainfall from February to March only accounts for 3\% 6\% of the total annual precipitation, inducing spring drought, causing surface cracking and soil layer spalling (Li et al., 2019). In this case, we have two aims: 1) estimate the effect on urban green space of effective soil amendments that have already successfully applied in agriculture; 2) compare the amelioration effects of organic and inorganic amendments.

\section{Materials and Methods}

\section{Soil selection and experiments}

The soil was collected at the roadsides of Guyuan City $\left(35^{\circ} 14^{\prime}-35^{\circ} 38^{\prime} \mathrm{N}\right.$, $\left.105^{\circ} 20^{\prime}-106^{\circ} 58^{\prime} \mathrm{E}\right)$, Ningxia Hui Autonomous Region, which lies in the Loess Plateau. Located in the arid area of northern China, Guyuan has a typical continental monsoon climate with a mean annual precipitation ranging between $250-820 \mathrm{~mm}$ and annual evaporation ranging from 1250 to $2000 \mathrm{~mm}$ (Chao et al., 2017). The dominant soil type in the study area is loessal Cambisol (Xue and An, 2018) with a loamy texture (clay 20\%, silt $60 \%$, sand $20 \%$ ), and its basic properties were as follows: $\mathrm{pH} 8.4$, soil organic carbon (SOC) $4.7 \mathrm{~g} / \mathrm{kg}$, soil total nitrogen (TN) $0.53 \mathrm{~g} / \mathrm{kg}$, soil total phosphorus (TP) $0.45 \mathrm{~g} / \mathrm{kg}$, soil total potassium (TK) $10.9 \mathrm{~g} / \mathrm{kg}$, alkaline nitrogen (AN) $43 \mathrm{mg} / \mathrm{kg}$, available phosphorus (AP) $7.5 \mathrm{mg} / \mathrm{kg}$, available potassium (AK) $123 \mathrm{mg} / \mathrm{kg}$. Before use, the soil was air-dried, homogenized and sieved $<2 \mathrm{~mm}$. Roots and other plant residues were carefully removed. There were 6 treatments with 3 replicates 5 soil amendments prepared in the experiment: They were soils amended with three common agricultural residues: animal manure (naturally air-dried cow manure without composting here, AM), mushroom residues (composted spent mushroom substrate, MR), plant residues (air-dried maize straw without further treatment, PR) and other two widely used inorganic amendments: synthetic polyvinyl alcohol (PVA), natural volcanic pumice (VOP). AM, $\mathrm{PR}$ and MR were ground to debris and sieved through $2 \mathrm{~mm}$ before use. PVA and VOP were powders. About $150 \mathrm{~g}$ air-dried soil was homogeneously mixed with the above-mentioned organic substrates and inorganic amendments at a ratio of $3 \% \mathrm{w} / \mathrm{w}$. The mixed soils were immediately filled into containers $(60 \mathrm{ml}$ tubes, $12 \mathrm{~cm}$ in height). The physical mixing of the soil was performed with the unamended control soil.

A modified cutting-ring method ( $\mathrm{Lu}, 2000)$ was adapted to evaluate the water holding capacity (WHC) of soils with a simulated precipitation and the following drainage process. Briefly, all tubes were submerged into the water for 6 hours to amke a saturation. Initial weight of each tube was recorded after taking out from water and standstill for 1-hour. Maximal water-holding capacity of soils were calculated by the weight difference of water-saturated soils and air-dried soils. The samples were then positioned outside, the weight of the tubes was recorded daily to estimate the changes of soil WHC during the drainage. After two cycles of wetting-drying, the soils was collected to measure enzyme activity, aggregate stability and microbial diversity. Soil aggregate stability was measured 
following the method developed by Le Bissonnais (2016) and expressed as mean weight diameter (MWD). MWD values above the threshold of 1.3 denoted stable soil structures (Le Bissonnais, 2016). Dehydrogenase and $\beta$-glucosidase activity were determined following the method of Casida et al. (1964) and Eivazi and Tabatabai (1990), respectively.

\section{Soil bacterial community assays}

Soil total genomic DNA was extracted from 0.5 gram of soil using the FastDNA Spin Kit for Soil (MP Biomedicals, Santa Ana, USA) according manufacturer's instructions. For more information on PCR procedure and sequence analysis could be referred to Feng et al. (2018).

Total 347,556 sequences of bacterial 16S rRNA gene with a range of 8,018 and 36,503 sequences per sample were obtained. Alpha diversity was calculated using 8,000 reads per sample (nearly closed to minimum number of sequences required to normalize the differences in sampling effort) with multiple indices (observed species (hereafter, Richness), Shannon-Winner index (hereafter, Shannon) and phylogenetic diversity (hereafter, PD)).

\section{Statistical analysis}

Statistical procedures were calculated using the IBM Statistical Product and Service Solutions (SPSS) Statistics for windows (Version 13). The data were expressed as the means with standard deviation (SD), and different letters indicated significant differences among different amendments. ANOVA was performed to determine the effects of amendments, followed by Tukey's HSD test. Differences of $\mathrm{P}<0.05$ were considered significant.

\section{Result}

\section{Changes of soil chemical and physical properties}

Important soil fertility indices such as $\mathrm{pH}$ and SOC, as well as soil aggregate stability were quantified (Fig. 1). Soil pH was slightly alkaline and not affected by the different amendments. Compared to the unamended soil $(\mathrm{Ctrl})$, AM amendment significantly increased the SOC content, while other amendments had no significant effects on SOC content $(p<0.05)$. AM and PR amendmentssignificantly increased the soil MWD value $(p<0.05)$. The results showed that animal manure could efficiently bind soil particles together very likely due to the increased SOC content. While, two inorganic amendments PVA and VOP did not alter soil proterties, regardless of chemical ( $\mathrm{pH}$ and SOC) and physical (MWD) features. However, MWD for all treatments was less than 1.3, close to the threshold which differentiates a stable from an unstable soil (Le Bissonnais, 2016). This indicates that improved soil structures in such soil-eroded areas are in scarcity and it would require prolonged periods of time or more amount of amendments to be formed.

\section{Changes of soil water holding capacity}

We further present the alteration of soil water holding capacity (WHC) among different amendments (Fig. 2), the results show very similar dynamic patterns with those observed for soil aggregate stability and SOC content (Fig. 1). Four amendments AM, PR, MR, and PVA had a higher WHC than Ctrl treatment, indicating an increased soil 
water storage capacity. It is obvious that three treatments of orgnic amendments had strogher effects than two treatments of inorangic amendments. In contrast, VOP amendment had no effects or even negative effects on WHC (Fig. 2 and Table 1).

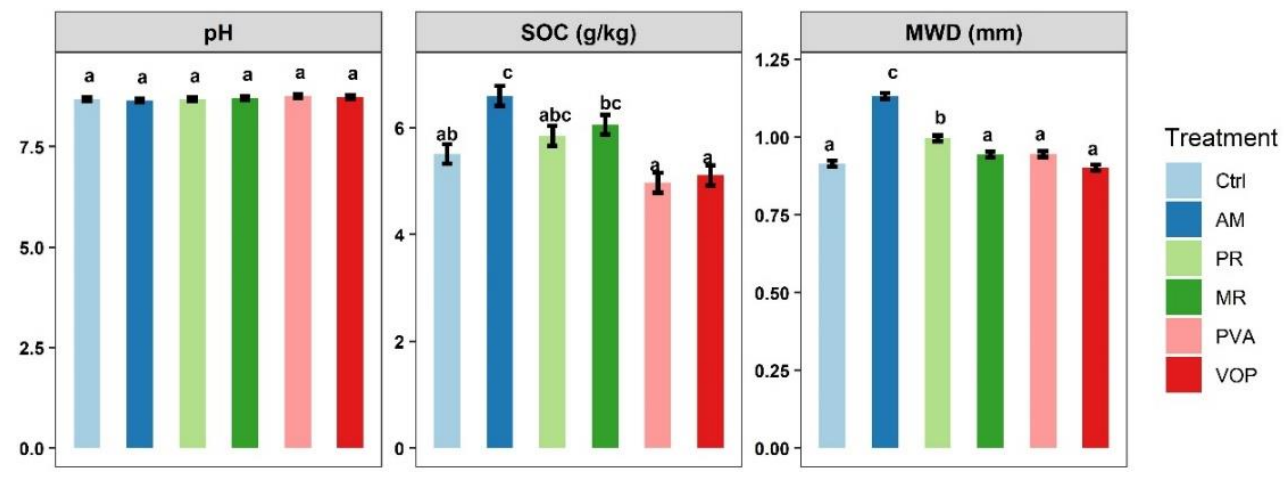

Figure 1. Soil pH, SOC content and aggregate stability (MWD, mean weight diameter) of soils amended with animal manure (AM), mushroom residue (MR), plant residue (PR), synthetic polyvinyl alcohol (PVA) and natural volcanic pumice (VOP). Different letters above bars denotes significant differences at $p<0.05$

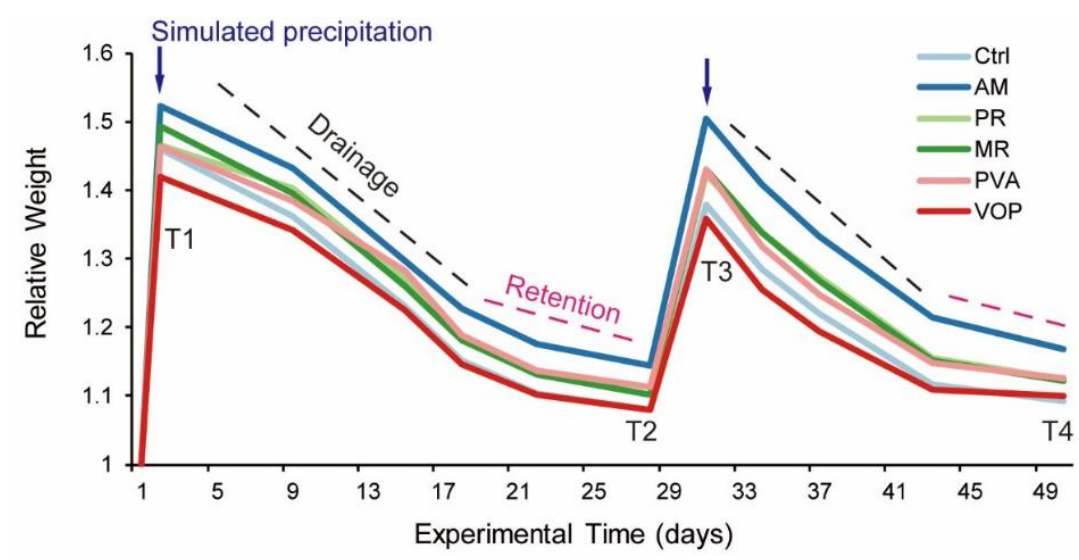

Figure 2. Changes of soil water holding capacity from soils amended with animal manure $(A M)$, mushroom residue (MR), plant residue (PR), synthetic polyvinyl alcohol (PVA) and natural volcanic pumice (VOP). Data were means of 3 replicates. Two peaks represent simulated heavy rainfall

Table 1. Soil water holding capacity among different amendments at four timepoints (corresponding to Figure 2)

\begin{tabular}{c|c|c|c|c}
\hline & T1 & T2 & T3 & T4 \\
\hline Ctrl & $1.46 \pm 0.01(\mathrm{~b})$ & $1.08 \pm 0.01(\mathrm{ab})$ & $1.38 \pm 0.01(\mathrm{ab})$ & $1.09 \pm 0.01(\mathrm{a})$ \\
AM & $1.52 \pm 0.01(\mathrm{~d})$ & $1.14 \pm 0.01(\mathrm{~d})$ & $1.5 \pm 0.02(\mathrm{c})$ & $1.17 \pm 0.02(\mathrm{c})$ \\
PR & $1.46 \pm 0.01(\mathrm{bc})$ & $1.1 \pm 0.01(\mathrm{bc})$ & $1.42 \pm 0.01(\mathrm{~b})$ & $1.12 \pm 0.01(\mathrm{~b})$ \\
MR & $1.49 \pm 0.01(\mathrm{~cd})$ & $1.1 \pm 0.01(\mathrm{bc})$ & $1.43 \pm 0.02(\mathrm{~b})$ & $1.12 \pm 0.01(\mathrm{~b})$ \\
PVA & $1.46 \pm 0.02(\mathrm{bc})$ & $1.11 \pm 0.01(\mathrm{c})$ & $1.43 \pm 0.02(\mathrm{~b})$ & $1.13 \pm 0.01(\mathrm{~b})$ \\
VOP & $1.42 \pm 0.02(\mathrm{a})$ & $1.08 \pm 0.01(\mathrm{a})$ & $1.36 \pm 0.03(\mathrm{a})$ & $1.1 \pm 0.02(\mathrm{ab})$ \\
\hline
\end{tabular}

Data were shown as mean \pm SD. Different letters in one column denote significant differences at $\mathrm{P}<0.05$

Across the two wetting-drainage cycles, AM consistently increased soil WHC $(P<0.05$, Fig. 2). Specifically, compared to $C t r l$, the soil with AM amendment could store 
$13 \%, 75 \%, 31 \%$ and $88 \%$ more water at $\mathrm{T} 1, \mathrm{~T} 2$, T3 and T4, repectively (Table. 1). It indicated that AM amendment was able to increase the maximal WHC during precipitation and maintain a higher moisture during drought. MR and PVA increased soil WHC after precipitation (T1) and drainage (T3) during first wetting-drainage cycle, respectively, while VOP significantly decreased soil WHC. During second cycle, PR, MR, PVA amendments all significantly increase soil WHC at drainage stage.

\section{Effects of soil amendments on bacterial diversity and activity}

The microbial communities developed at different soil amendment conditions after nearly 60 days of two cycles of wetting-drainage process were investigated. A dataset of 347,556 quality sequences were produced from all soil samples, with almost all classified to the kingdom of bacteria. The total number of OTUs was 2,640 defined by $97 \%$ sequence similarity. Both AM and PR amendments significantly increased the bacterial Richness, Shannon values $(p<0.05)$, with AM having the largest effect among all amendments. MR imposed no significant impact on bacterial community at taxonomic level (Richness and Shannon) ( $p>0.05)$, while VOP significantly decreased the bacterial diversity at both taxonomic diversities (Richness and Shannon) $(p<0.05)$ (Fig. 3).

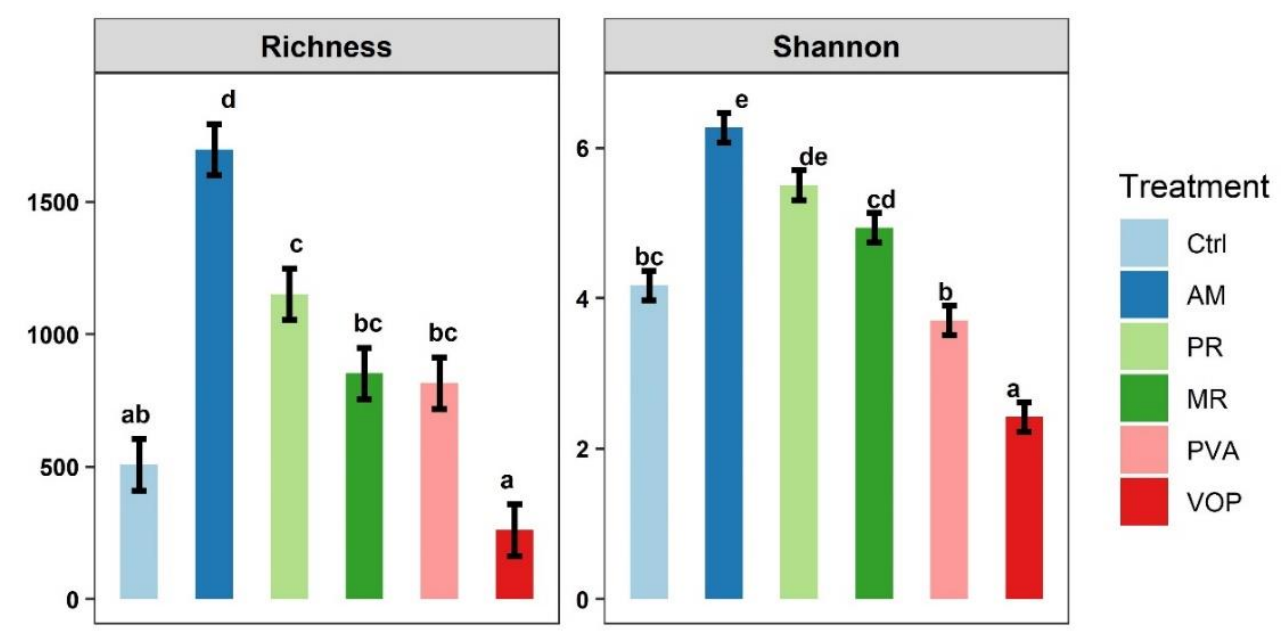

Figure 3. Bacterial community diversity of soils amended with animal manure (AM), mushroom residues $(M R)$, plant residues $(P R)$, synthetic polyvinyl alcohol $(P V A)$ and natural volcanic pumice (VOP). Data are means of 3 replicates (mean $\pm S D$ ). Different letters above bars denote significant differences at $p<0.05$

The dehydrogenase and $\beta$-glucosidase were used to estimate the influence of the amendments on soil microbial activities to indicate the degradation of organic matter as well as its nutrient turnover capacities (Schröder et al., 2014). Compared to the unamended soil, AM, MR, and PR all significantly increased the soil dehydrogenase and $\beta$-glucosidase activities $(p<0.05)$, while PVA and VOP imposed no evident, impact $(p>0.05)$ (Fig. 4). AM imposed the greatest positive impact on the two important soil enzymes; this indicated that animal manure could efficiently increase soil biogeochemical activity. This observation was consistent with the significant increase in SOC content (Fig. 1). 


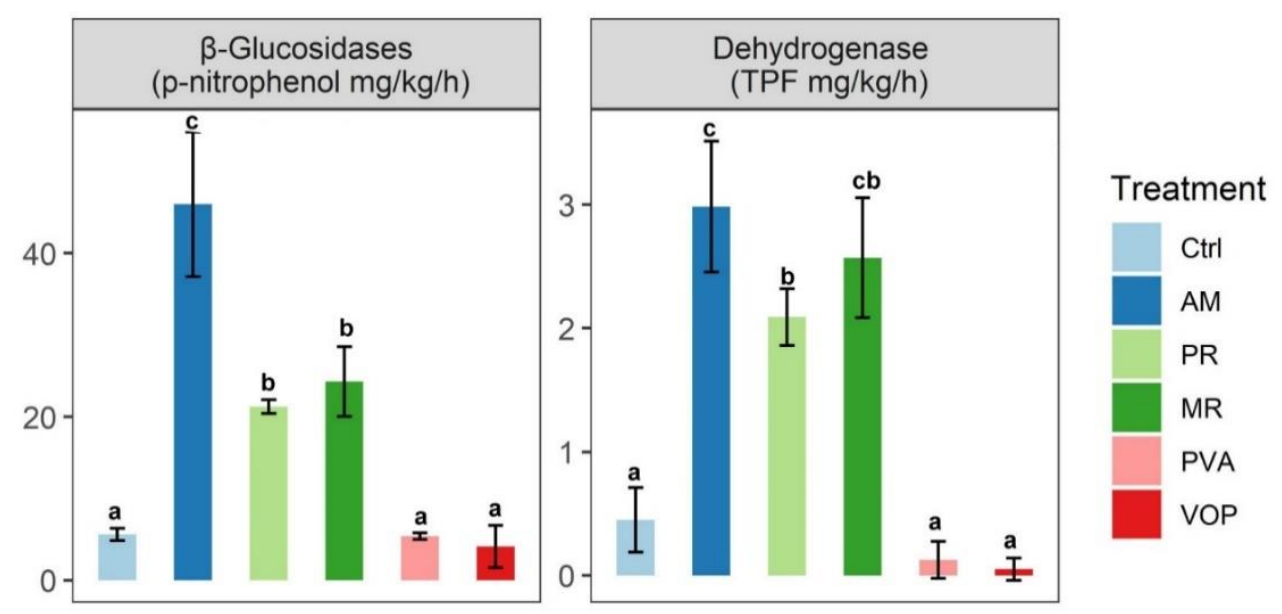

Figure 4. $\beta$-glucosidase and dehydrogenase activity of soils amended with animal manure $(A M)$, mushroom residues $(M R)$, plant residues $(P R)$, synthetic polyvinyl alcohol $(P V A)$ and natural volcanic pumice (VOP). Data are means of 3 replicates $\pm 1 S D$. Different letters above bars denote significant differences at threshold $p<0.05$

\section{Discussion}

Soil quality is strongly defined by several interactions between chemical and biological components, including soil organic matter and microbial community, which both play key roles on soil fertility (Faissal et al., 2017). As a typical place in the Loess Plateau, Guyuan is characterized with a rather poor soil quality (Fig. 1). The MWD is rather less than 1.3 , the threshold that indicates a relative stable soil structure (Le Bissonnais, 2016), and its soil fertility is also quite lower than the typical infertile soil (Feng et al., 2015). In this study, overall, organic amendments significantly increased SOC content, soil aggregate stability as well as the concomitant soil water holding capacity and microbial diversity/activity in different degree, while inorganic amendments didn't impose any beneficial effect (Figs. 1-4).

Accelerating number of studies have confirmed that organic amendments (manure, straw, fermentation, etc.) could be used to improve soil structure (i.e., increase soil porosity and aggregate stability, but decrease bulk density) and fertility mainly by increased SOC (Garccía-Orenes et al., 2005; Peregrina et al., 2012; Li et al., 2014). In this process, soil microorganisms drive the turnover of humic substances which could increase the connectivity of soil particles. In addition, they are the primary means by which nutrients in organic matter can be utilized by plants and other autotrophs (Bell et al., 2005; Verchot et al., 2011). When soil structure improves through aggregation by binding soil particles together (Fig. 1), it provides with a proper niche for soil microbial community (Chen et al., 2017). Indeed, we observed consistent dynamic patterns on the increased soil bacterial diversity (Fig. 3) and enzyme activities (Fig. 4) with organic amendments. It is acknowledged that microbial communities with relatively high biodiversity could transform carbon from organic debris into biomass at accelerated rates with higher conversion efficiency (Maeder et al., 2002; Bell et al., 2005; Patsch et al., 2018). These results were consistent with other previous studies. For example, Maeder et al. (2002) found that organic manure supports a diverse and active biotic community which could decompose more carbon than the ones present in conventional soil. In addition, manure amendments could also inhibit the pathogenic microbes in soil; thus, 
reduce plant diseases (i.e. scab and wilt incidence) (Conn and Lazarovits, 1999). Taking together, with the significant effect on improving soil structure and fertility, organic amendments could strengthen the roles of urban green space to regulate and conserve surface water source in the Loess Plateau (Fig. 2).

Among all organic amendments in this study, we consistently observed that animal manure surpasses plant and mushroom residues on their soil amelioration effects in both physical and biochemical properties. This is likely relevant to animal-source manure's feature as it is primarily composed of labile fractions (Xing et al., 2012; Wang et al., 2019) as a result of the intestinal digestion. In comparison, plant and mushroom residues are more recalcitrant due to their higher fractions of lignin and cellulose (Bao et al., 2019; Wang et al., 2019). Easily degradable carbon substances impose an intense effect on soil quality while more recalcitrant ones, such as lignin and cellulose, usually have lower effects (Diacono and Montemurro, 2010). Mushroom substrate has been used as a soil amendment due to its high organic matter content as well as other nutrients, however, it usually takes up to 4 years to present a steady beneficial effect on soil quality due to its recalcitrant nature (Peregrina et al., 2012). Similar studies showed that amendments of organic materials from ex situ farmlands (animal manure, and other residues) could also promote soil quality more efficiently compared to in situ similar additives (Long et al., 2015). However, we should bear in mind that animal manure should be processed in harmless treatment to avoid negative effects such as the contamination of antibiotics (Peng et al., 2015) and heavy metals (Ji et al., 2012). Composted manure after batch fermentation, to a large degree, could overcome such problems (Peng et al., 2015).

As expected, inorganic amendments imposed less effect on either soil physical or biochemical properties than organic amendments (Figs. 1-4). PVA (polyvinyl alcohol) is a type of uncharged synthetic organic polymer used as soil conditioner (Blavia et al., 1971). With plausible interaction between the polymers and the clay surface via hydrogen binding, PVA could efficiently protect the soil from water ingress (Stefanson, 1973). Consistently, in this case we found that the water hold capability was increased by PVA amendment. However, the other soil properties were not improved. The underlying reason could be that PVA characteristics were dependent on the soil carbon content and humidity (Moayedi et al., 2011), both of which are rarely available in the Loess Plateau where the poor soil quality (silt-dominated, but not clay) and limited precipitation are the two major threats. Additionally, PVA can become easily degradable, implying that it would just impose an intense but transient effect on the soil properties as well as soil microorganisms (Wiśniewska, 2010). VOP is a prospering naturally-suited, hardly degradable soil conditioner with numerous beneficial effect for the soil properties (Noland et al., 1992; Cruz-Ruíz et al., 2016). However, in this study, VOP imposed no effect on the soil's physical and/or biochemical properties when compared to other amendments. Similar phenomena were also reported by Temiz and Cayci (2018), who found that pumice had little effect on soil aggregation, compared to plant residues. Given the fact that evaporation is often larger than precipitation in the Loess Plateau (Chao et al., 2017), plausible high mineral content in VOP amendments (Cruz-Ruíz et al., 2016) could even deteriorate soil quality via increased soil salinity (de Meester, 1970). In addition, considering the main constraint in the Loess Plateau was the rather low SOM content (Guo et al., 2019), VOP could offer nothing to improve, if not worsen the status of soil functioning as a carbon sink (Fig. 1). Above all, VOP and PVA amendments alone could not impose long-last beneficial effects, and thus were inappropriate to improve the soil structure in arid areas. 


\section{Conclusion}

Application of exogenous amendments can affect the soil structure and bacterial community in soils from the arid area of the Loess Plateau. Compared with the widely used inorganic soil amendments (i.e. polyvinyl alcohol and volcanic pumice), organic amendments (animal manure, plant residue and mushroom residue) significantly increased soil water holding capacity, aggregate stability as well as microbial diversity and activity. Overall, animal manure imposed the greatest beneficial effect to the soil properties, followed by plant residue and mushroom residue. Animal manure could function as soil amendment for urban green space in the Loess Plateau and other regions with similar soil properties.

Acknowledgements. We are grateful to Mr. Ke Tian for soil sample collection.

\section{REFERENCES}

[1] Bao, Y., Dolfing, J., Wang, B., Chen, R., Huang, M., Li, Z., Lin, X., Feng, Y. (2019): Bacterial communities involved directly or indirectly in the anaerobic degradation of cellulose. - Biology and Fertility of Soils 55: 201-211.

[2] Bell, T., Newman, J. A., Silverman, B. W., Turner, S. L., Lilley, A. K. (2005): The contribution of species richness and composition to bacterial services. - Nature 436: 11571160 .

[3] Blavia, F. J., Moldenhauer, W. C., Law, D. E. (1971): Soil and water management and conservation. - Soil Science Society of America Journal 35.

[4] Bouranis, D. L., Theodoropoulos, A. G., Drossopoulos, J. B. (2008): Designing synthetic polymers as soil conditioners. - Communications in Soil Science and Plant Analysis 26: 1455-1480.

[5] Cai, Y., Chen, Y., Tong, C. (2019): Spatiotemporal evolution of urban green space and its impact on the urban thermal environment based on remote sensing data: A case study of Fuzhou City, China. - Urban Forestry and Urban Greening 41: 333-343.

[6] Casida, L. E. J., Klein, D. A., Santoro, T. (1964): Soil Dehydrogenase Activity. - Soil Science 98: 371-376.

[7] Chan, F. K. S., Griffiths, J. A., Higgitt, D., Xu, S., Zhu, F., Tang, Y., Xu, Y., Thorne, C. R. (2018): "Sponge City" in China-A breakthrough of planning and flood risk management in the urban context. - Land Use Policy 76: 772-778.

[8] Chang, R. X., Yao, Y., Cao, W. C., Wang, J., Wang, X., Chen, Q. (2019): Effects of composting and carbon-based materials on carbon and nitrogen loss in the arable land utilization of cow manure and corn stalks. - Journal of Environmental Management 233: 283-290.

[9] Chao, W., Lin, Z., Bingzhen, D. (2017): Assessment of the impact of China's Sloping Land Conservation Program on regional development in a typical hilly region of the Loess plateau-A case study in Guyuan. - Environmental Development 21: 66-76.

[10] Chen, Z., Wang, H., Liu, X., Zhao, X., Lu, D., Zhou, J., Li, C. (2017): Changes in soil microbial community and organic carbon fractions under short-term straw return in a ricewheat cropping system. - Soil and Tillage Research 165: 121-127.

[11] Chen, M., Dai, F., Yang, B., Zhu, S. (2019): Effects of urban green space morphological pattern on variation of PM2.5 concentration in the neighborhoods of five Chinese megacities. - Building and Environment 158: 1-15.

[12] Conn, K. L., Lazarovits, G. (1999): Impact of animal manures on verticillium wilt, potato scab, and soil microbial populations. - Canadian Journal of Plant Pathology 21: 81-92. 
[13] Cruz-Ruíz, A., Cruz-Ruíz, E., Vaca, R., Del Aguila, P., Lugo, J. (2016): Effects of pumice mining on soil quality. - Solid Earth 7: 1-9.

[14] de Meester, T. (1970): Soils of great Kanya Basin, Turkey. - Agricultural Research Reports 740, Centre for Agricultural Publishing and Documentation, Wageningen.

[15] Diacono, M., Montemurro, F. (2010): Long-term effects of organic amendments on soil fertility. A review. - Agronomy for Sustainable Development 30: 401-422.

[16] Eivazi, F., Tabatabai, M. A. (1990): Factors affecting glucosidase and galactosidase activities in soils. - Soil Biology and Biochemistry 22: 891-897.

[17] Faissal, A., Ouazzani, N., Parrado, J. R., Dary, M., Manyani, H., Morgado, B. R., Barragán, M. D., Mandi, L. (2017): Impact of fertilization by natural manure on the microbial quality of soil: Molecular approach. - Saudi journal of biological sciences 24: 1437-1443.

[18] Feng, Y., Chen, R., Hu, J., Zhao, F., Wang, J., Chu, H., Zhang, J., Dolfing, J., Lin, X. (2015): Bacillus asahii comes to the fore in organic manure fertilized alkaline soils. - Soil Biology and Biochemistry 81: 186-194.

[19] Feng, Y., Chen, R., Stegen, J. C., Guo, Z., Zhang, J., Li, Z., Lin, X. (2018): Two key features influencing community assembly processes at regional scale: Initial state and degree of change in environmental conditions. - Molecular Ecology 27: 5238-5251.

[20] Follett, R. F., Varvel, G. E., Kimble, J. M., Vogel, K. P. (2009): No-Till Corn after Bromegrass: Effect on Soil Carbon and Soil Aggregates. - Agronomy Journal 101: 261268.

[21] Garccía-Orenes, F., Guerrero, C., Mataix-Solera, J., Navarro-Pedreño, J., Gómez, I., Mataix-Beneyto, J. (2005): Factors controlling the aggregate stability and bulk density in two different degraded soils amended with biosolids. - Soil and Tillage Research 82: 6576.

[22] Gong, Y., Tang, J., Zhao, D. (2016): Application of iron sulfide particles for groundwater and soil remediation: A review. - Water Research 89: 309-320.

[23] Guo, Z., Zhang, J., Fan, J., Yang, X., Yi, Y., Han, X., Wang, D., Zhu, P., Peng, X. (2019): Does animal manure application improve soil aggregation? Insights from nine long-term fertilization experiments. - Science of The Total Environment 660: 1029-1037.

[24] Hua, L., Zhong, L., Ke, Z. (2016): Precipitation recycling and soil-precipitation interaction across the arid and semi-arid regions of China. - International Journal of Climatology 36: 3708-3722.

[25] Ji, X., Shen, Q., Liu, F., Ma, J., Xu, G., Wang, Y., Wu, M. (2012): Antibiotic resistance gene abundances associated with antibiotics and heavy metals in animal manures and agricultural soils adjacent to feedlots in Shanghai; China. - Journal of Hazardous Materials 235-236: 178-185.

[26] Karlen, D. L., Andrews, S. S., Wienhold, B. J., Zobeck, T. M. (2008): Soil Quality Assessment: Past, Present and Future. - J. Integr. Biosci. 6(1): 3-14.

[27] Khan, M. A., Khan, S., Khan, A., Alam, M. (2017): Soil contamination with cadmium, consequences and remediation using organic amendments. - Science of The Total Environment 601-602: 1591-1605.

[28] Le Bissonnais, Y. (2016): Aggregate stability and assessment of soil crustability and erodibility: I. Theory and methodology. - European Journal of Soil Science 67: 11-21.

[29] Li, J., Lu, J., Li, X., Ren, T., Cong, R., Zhou, L. (2014): Dynamics of potassium release and adsorption on rice straw residue. - PloS one 9: e90440-e90440.

[30] Li, Y., Xie, Z., Qin, Y., Xia, H., Zheng, Z., Zhang, L., Pan, Z., Liu, Z. (2019): Drought Under Global Warming and Climate Change: An Empirical Study of the Loess Plateau.Sustainability 11: 1281-1295.

[31] Liu, Z., Liu, F., Ma, F., Wang, M., Bai, X., Zheng, Y., Yin, H., Zhang, G. (2015): Collapsibility, composition, and microstructure of loess in China. - Canadian Geotechnical Journal 53: 673-686. 
[32] Long, P., Sui, P., Gao, W., Wang, B., Huang, J., Yan, P., Zou, J., Yan, L., Chen, Y. (2015): Aggregate stability and associated $\mathrm{C}$ and $\mathrm{N}$ in a silty loam soil as affected by organic material inputs. - Journal of Integrative Agriculture 14: 774-787.

[33] Lu, R. (2000): Analytical methods for soil and agrochemistry. - Beijing, Chinese Agriculture Science and Technology Press. (In Chinese).

[34] Maeder, P., Fliessbach, A., Dubois, D., Gunst, L., Fried, P., Niggli, U. (2002): Soil Fertility and Biodiversity in Organic Farming. - Science 296: 1694-1697.

[35] Miao, S. J., Shi, H., Wang, G. H., Jin, J., Liu, J. D., Zhou, K. Q., Sui, Y. Y., Liu, X. B. (2013): Seven years of repeated cattle manure addition to eroded Chinese Mollisols increase low-molecular-weight organic acids in soil solution. - Plant and Soil 369: 577584.

[36] Moayedi, H., Asadi, A., Moayedi, F., Huat, B. B. K. (2011): Zeta Potential of Tropical Soil in Presence of Polyvinyl Alcohol. - International Journal of Electrochemical Science 6: 1294-1306.

[37] Noland, D. A., Spomer, L. A., Williams, D. J. (1992): Evaluation of pumice as a perlite substitute for container soil physical amendment. - Communications in Soil Science and Plant Analysis 23: 1533-1547.

[38] Patsch, D., van Vliet, S., Marcantini, L. G., Johnson, D. R. (2018): Generality of associations between biological richness and the rates of metabolic processes across microbial communities. - Environental Microbiology 20: 4356-4368.

[39] Peng, S., Wang, Y., Zhou, B., Lin, X. (2015): Long-term application of fresh and composted manure increases tetracycline resistance in the arable soil of eastern China. Science of The Total Environment 506-507: 279-286.

[40] Peregrina, F., Larrieta, C., Colina, M., Mariscal-Sancho, I., Martín, I., Martínez-Vidaurre, J. M., García-Escudero, E. (2012): Spent Mushroom Substrates Influence Soil Quality and Nitrogen Availability in a Semiarid Vineyard Soil. - Soil Science Society of America Journal 76(5): 1655-1666.

[41] Schröder, C., Elleuche, S., Blank, S., Antranikian, G. (2014): Characterization of a heatactive archaeal $\beta$-glucosidase from a hydrothermal spring metagenome. - Enzyme and Microbial Technology 57: 48-54.

[42] Stefanson, R. C. (1973): Polyvinyl alcohol as a stabilizer of surface soils. - Soil Science 115(6): 420-428.

[43] Su, C. C., Ma, J. F., Chen, Y. P. (2019): Biochar can improve the soil quality of new creation farmland on the Loess Plateau. - Environmental Science and Pollution Research 26: $2662-2670$.

[44] Sun, J. (2002): Provenance of loess material and formation of loess deposits on the Chinese Loess Plateau. - Earth and Planetary Science Letters 203: 845-859.

[45] Sun, J., Guo, X., Liang, J., Chen, G., Zhang, G., Zhou, T. (2017): Effects of mulching time on soil temperature and moisture and potato yield in the hilly area of Southern Ningxia. Acta Prataculturae Sinica 26: 24-34.

[46] Tang, H. M., Xiao, X. P., Li, C., Wang, K., Guo, L. J., Cheng, K. K., Sun, G., Pan, X. C. (2018): Impact of long-term fertilization practices on the soil aggregation and humic substances under double-cropped rice fields. - Environmental Science and Pollution Research 25: 11034-11044.

[47] Temiz, C., Cayci, G. (2018): The effects of gypsum and mulch applications on reclamation parameters and physical properties of an alkali soil. - Environmental Monitoring and Assessment 190: 347.

[48] Tisdall, J. M., Oades, J. M. (1982): Organic matter and water-stable aggregates in soils. Journal of Soil Science 33: 141-163.

[49] Verchot, L. V., Dutaur, L., Shepherd, K. D., Albrecht, A. (2011): Organic matter stabilization in soil aggregates: Understanding the biogeochemical mechanisms that determine the fate of carbon inputs in soils. - Geoderma 161: 182-193. 
[50] Vienneau, D., de Hoogh, K., Faeh, D., Kaufmann, M., Wunderli, J. M., Röösli, M. (2017): More than clean air and tranquillity: Residential green is independently associated with decreasing mortality. - Environment International 108: 176-184.

[51] Wang, K., Mao, H., Li, X. (2018): Functional characteristics and influence factors of microbial community in sewage sludge composting with inorganic bulking agent. Bioresource Technology 249: 527-535.

[52] Wang, Z., Yun, S., Xu, H., Wang, C., Zhang, Y., Chen, J., Jia, B. (2019): Mesophilic anaerobic co-digestion of acorn slag waste with dairy manure in a batch digester: Focusing on mixing ratios and bio-based carbon accelerants. - Bioresource Technology 286: 121394.

[53] Wiśniewska, M. (2010): The structure of electrical double layer of silica in the presence of polyvinyl alcohol (PVA) at different temperatures. - Materials Letters 64: 1611-1613.

[54] Wu, S., Wu, P., Feng, H., Bu, C. (2010): Influence of amendments on soil structure and soil loss under simulated rainfall China's Loess plateau. - African Journal of Biotechnology 9: 6116-6121.

[55] Xing, M., Li, X., Yang, J., Huang, Z., Lu, Y. (2012): Changes in the chemical characteristics of water-extracted organic matter from vermicomposting of sewage sludge and cow dung. - Journal of Hazardous Materials 205-206: 24-31.

[56] Xu, H., Wang, X. (2016): Effects of altered precipitation regimes on plant productivity in the arid region of northern China. - Ecological Informatics 31: 137-146.

[57] Xue, Z., An, S. (2018): Changes in Soil Organic Carbon and Total Nitrogen at a Small Watershed Scale as the Result of Land Use Conversion on the Loess Plateau. Sustainability 10: 1-14.

[58] Zhang, F., Cui, Z., Fan, M., Zhang, W., Chen, X., Jiang, R. (2011): Integrated Soil-Crop System Management: Reducing Environmental Risk while Increasing Crop Productivity and Improving Nutrient Use Efficiency in China. - Journal of Environmental Quality 40: 1051-1057.

[59] Zhang, Y., Guo, S., Liu, Q., Jiang, J. (2014): Influence of soil moisture on litter respiration in the semiarid Loess plateau. - PloS one 9: e114558.

[60] Zhang, J. Y., Sun, C. L., Liu, G. B., Xue, S. (2018): Effects of long-term fertilization on aggregates and dynamics of soil organic carbon in a semi-arid agro-ecosystem in China.Peerj 6: e4758.

[61] Zou, P., Fu, J. R., Cao, Z. H., Ye, J., Yu, Q. G. (2015): Aggregate dynamics and associated soil organic matter in topsoils of two 2,000-year paddy soil chronosequences. - Journal of Soils and Sediments 15: 510-522. 